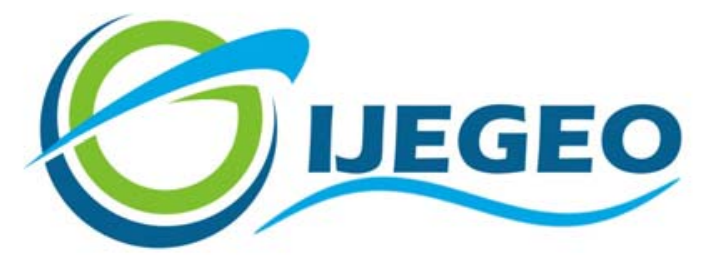

International Journal of Environment and Geoinformatics (IJEGEO) is an international, multidisciplinary, peer reviewed and certified open access journal.

\title{
Performance of the Persulfate/UV-C Process for the Treatment of Dimethyl Phthalate from Aquatic Environments
}

\author{
Tuğba ÖImez-Hancı, İdil Arslan-Alaton and Ceren İmren \\ Editors \\ Prof. Dr. Cem Gazioğlu, Prof. Dr. Dursun Zafer Şeker, Prof. Dr. Ayşegül Tanık, \\ Prof. Dr. Şinasi Kaya, Assist. Prof. Dr. Volkan Demir
}

\section{Scientific Committee (2018)}

Dr. Abdullah Aksu, Prof. Dr. Bedri Alpar, Prof. Dr. Gülşen Altuğ, Prof. Dr. Lale Balas, Prof. Dr. Can Balas, Prof. Dr. Levent Bat, Prof. Dr. Bülent Bayram, Prof. Dr. Nuray Çağlar, Prof. Dr. Jadunandan Dash, Prof. Dr. A. Evren Erginal, Dr. Dieter Fritsch, Dr. Amin Gharehbaghi, Assoc. Prof. Dr. Tolga Görüm, Prof. Dr. Melike Gürel, Dr. Hakan Kaya , Prof. Dr. Fatmagül Kılıç, Assoc. Prof. Dr. Maged Marghany, Prof. Dr. Nebiye Musaoğlu, Prof. Dr. Masafumi Nakagawa, Prof. Dr. Haluk Özener, Prof. Dr. Erol Sarı, Prof. Dr. Elif Sertel, Prof. Dr. Nüket Sivri, Assoc. Prof. Dr. Füsun Balık Şanlı, Prof. Dr. Uğur Şanlı, Assoc. Prof. Dr. Hasan Özdemir, Prof. Dr. Taşkın Kavzoğlu, Msc. Mustafa Üstüner, Assoc. Prof. Dr. Oral Yağcı, Prof. Dr. Seyfettin Taş, Assoc. Prof. Dr. Ömer Suat Taşkın, Assoc. Prof. Dr. İ. Noyan Yılmaz, Dr. Baki Yokeş, Dr. Sibel Zeki 


\title{
Performance of the Persulfate/UV-C Process for the Treatment of Dimethyl Phthalate from Aquatic Environments
}

\author{
Tuğba Ölmez-Hancı*, İdil Arslan-Alaton, Ceren İmren \\ Istanbul Technical University, Environmental Engineering Department, 34469 Maslak, Istanbul, Turkey

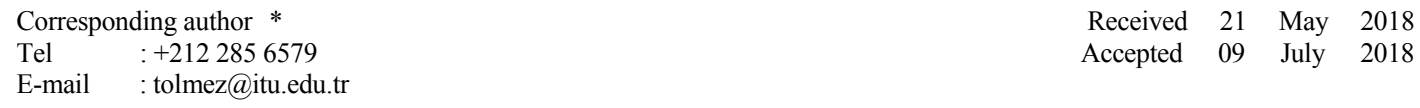

\begin{abstract}
Phthalate esters (PAEs) are used as plasticizers to impart flexibility and resilience to plastic products. In recent years, PAEs are a controversial issue because many phthalates are suspected to be mutagens, hepatotoxic agents and endocrine disruptors, and can lead to adverse effects on organisms even in a low concentration. Recently, sulfate $\left(\mathrm{SO}_{4}{ }^{-}\right)$radical based advanced oxidation processes have attracted great scientific interest due to their high efficiency in the degradation and mineralization of recalcitrant and/or toxic organic pollutants. In the present study aqueous dimethyl phthalate (DMP; $100 \mathrm{mg} \mathrm{L}^{-1}$ ), being selected as a model PAE, was treated by the persulfate (PS)/UV-C process at $\mathrm{pH} 3$ and varying PS concentrations (0-60 mM). DMP and TOC abatements increased with increasing PS concentrations from 5 to $40 \mathrm{mM}$. Further increase in the initial PS concentration, however, reduced both the rate and extent of DMP and TOC removals. The highest pseudo-first-order abatement rate coefficient and electrical energy per order $(\mathrm{EE} / \mathrm{O})$ values obtained for DMP treatment with PS/UV-C oxidation were found as $0.4493 \mathrm{~min}^{-1}$ and $1.79 \mathrm{kWh} \mathrm{m}^{-3}$ order $^{-1}$, respectively, for $\mathrm{PS}=30 \mathrm{mM}, \mathrm{pH}=3, \mathrm{DMP}=100 \mathrm{mg} \mathrm{L}^{-1}$. The secondorder reaction rate coefficient for DMP with $\mathrm{SO}_{4}{ }^{--}$was determined as $1.47 \times 10^{9} \mathrm{M}^{-1} \mathrm{~s}^{-1}$ by the application of competition kinetics using phenol as the probe compound. Within the scope of the present study, aqueous DMP was also subjected to peroxymonosulfate (PMS)/UV-C and hydrogen peroxide (HP)/UV-C treatments. The performance of PS/UV-C treatment was found to be higher than that of PMS/UV-C and HP/UV-C treatments both in terms of DMP and TOC abatement rates at an initial oxidant concentration of $5 \mathrm{mM}$.
\end{abstract}

Keywords: Dimethyl phthalate, Endocrine disrupting compound, Reaction kinetics, Sulfate radical.

\section{Introduction}

Phthalate esters (PAEs) are ubiquitous pollutants in the environment, due to their widespread use for around 50 years. The phthalates are mainly used as additives in plastics, especially in plasticized polyvinyl chloride (PVC), as well as in the production of paints and varnishes, adhesives, lubricants and cosmetics. The most widely used representative PAEs is bis(2ethylhexyl) phthalate (DEHP) (Clara et al., 2010), which is the dominant plasticizer used in PVC production. Another common PAE is Benzyl butyl phthalate (BBP), which is also used in the manufacture of foamed PVC. The PAEs with relatively short alkyl chains such as dimethyl phthalate (DMP), diethyl phthalate (DEP), and di-n-butyl phthalate (DBP) are used as solvents in perfumes and pesticides (Oliver et al., 2005). Since PAEs are not covalently bonded to the polymeric matrix they are easily leached into the environment during the process of plastic aging and decomposition (Dargnat et al., 2009). In addition, these pollutants are refractory to biodegradation in the environment by microorganisms, leading to their widespread presence in the environment (Abdel daiem et al., 2012). Therefore, due to the high consumption, the continuous release to the environment and their resistance to microbial decomposition, many PAEs are found to be ubiquitously present in the environment, including rainwater/stormwater, surface water, sediments, and soils (Kolpin et al., 2002; Fierens et al., 2012; Kang et al., 2012). PAEs are known to be hazardous chemicals to human health since they have been associated to birth defects, organ damage, infertility and cancer. They are also known to be among the endocrine disrupting compounds present in water (Venkata et al., 2007). 
PAEs cannot be removed effectively by conventional water/wastewater treatment processes. PAEs with long alkyl-chains are poorly degraded and some of them are considered recalcitrant to biological degradation (Bauer et al., 1998). It is necessary to develop alternative treatment technologies that can effectively remove PAEs from waters and wastewaters. Advanced oxidation processes (AOPs) using highly reactive radicals such as hydroxyl radicals $\left(\mathrm{HO}^{\circ}\right)$ are applied for the treatment of PAEs (Xua et al., 2007; Zhou et al., 2007; Yuan et al., 2008; Ölmez-Hanc1 et al., 2009). Sulfate radical $\left(\mathrm{SO}_{4}{ }^{-}\right)$-based $\mathrm{AOPs}$, in which persulfate (PS) or peroxymonosulfate (PMS) are used as oxidants, came forth recently for the degradation of toxic and/or refractory pollutants. Previous studies showed that the $\mathrm{SO}_{4}{ }^{-}$can be generated by the activation of PS or PMS using transition metal ions, thermal energy, UV-C irradiation or other activators (Criquet and Leitner, 2009). Activation of PS under UV-C radiation results in the formation of two $\mathrm{SO}_{4}{ }^{-}$ (Equation (1)) through the homolytic cleavage of the peroxide (-O-O-) bond (Baxendale and Wilson, 1957; Mark et al., 1990; Anipsitakis and Dionysiou, 2004);

$\mathrm{S}_{2} \mathrm{O}_{8}{ }^{2-}+\mathrm{h} v \rightarrow 2 \mathrm{SO}_{4}^{--}$

(Eq. 1)

$\mathrm{SO}_{4}{ }^{--}$is very reactive due to its high reduction potential $\left(\mathrm{E}_{\mathrm{o}}=2.5-3.1 \mathrm{eV}\right)$, leading to a great potential for degrading organic compounds in wastewater (Neta et al., 1988). Therefore, the PS/UV-C process has been confirmed to be effective in degrading organic contaminants (Anipsitakis and Dionysiou, 2004; He et al., 2013; Yang et al., 2016).

This study was undertaken to investigate the treatability of DMP, which was selected as the target PAE because of its frequent detection in the aquatic environment, by the PS/UV-C process. The effect of initial PS concentration on DMP and its total organic carbon (TOC) removal rates was explored. The second-order reaction rate coefficient of DMP with $\mathrm{SO}_{4}{ }^{--}$was determined by employing competitive kinetics by using phenol as the reference compound. Finally, treatment performance of the PS/UV-C process was compared with the PMS/UV-C and hydrogen peroxide (HP)/UV-C oxidation processes (two known UV-driven AOPs) both in terms of DMP and TOC abatements.

\section{Materials and Methods}

Materials

DMP (Sigma-Aldrich, Germany; $\mathrm{C}_{10} \mathrm{H}_{10} \mathrm{O}_{4}$; purity: $>99 \%$ ) and phenol (Merck, Germany; $\mathrm{C}_{6} \mathrm{H}_{6} \mathrm{O}$; purity: $>99 \%$ ) were used as received. Potassium persulfate (PS, $\mathrm{K}_{2} \mathrm{~S}_{2} \mathrm{O}_{8},>99.5 \%$ ) and potassium peroxymonosulfate (PMS, $2 \mathrm{KHSO}_{5} \cdot 3 \mathrm{KHSO}_{4} \cdot 3 \mathrm{~K}_{2} \mathrm{SO}_{4}$ available as Oxone ${ }^{\circledR}$, $\geq 99.5 \%$ ) were purchased from Sigma-Aldrich, (Germany), $\mathrm{H}_{2} \mathrm{O}_{2}$ (HP, 35\%, w/w) from Merck (Germany). Aqueous DMP solutions were prepared in distilled water (Arium 61316RO, Sartorius AG, Germany), whereas for the preparation of the high performance liquid chromatography (HPLC) mobile phase and standard HPLC calibration solutions doubly distilled water (Arium 611UV system, Sartorius AG, Germany) was used. All other reagents and solvents were of at least analytical grade and obtained from Merck (Germany), Fluka (USA) or Sigma-Aldrich (USA).

\section{Experimental Procedures}

$\mathrm{PS} / \mathrm{UV}-\mathrm{C}, \mathrm{PMS} / \mathrm{UV}-\mathrm{C}$ and $\mathrm{HP} / \mathrm{UV}-\mathrm{C}$ treatment experiments were conducted in a $1.9 \mathrm{~L}$ capacity, cylindrical stainless-steel photoreactor (length = $95 \mathrm{~cm}$; diameter $=6 \mathrm{~cm}$ ) at room temperature $\left(25 \pm 2{ }^{\circ} \mathrm{C}\right)$. The UV-C photoreactor setup featuring the UV-C light source $\left(\lambda_{\max }=253.7\right.$ $\mathrm{nm})$ and the procedure of a typical experimental run were previously described elsewhere in more detail (Ölmez-Hanc1 et al., 2011). The batchoperated photoreactor was mixed by means of a peristaltic pump at a flow rate of $80 \mathrm{~mL} \mathrm{~min}^{-1}$. Samples were taken at regular time intervals for up to $60 \mathrm{~min}$ and analyzed for DMP, TOC and $\mathrm{pH}$. The second-order rate coefficient for the reaction of DMP with $\mathrm{SO}_{4}{ }^{--}$was determined by employing the competitive kinetics h. For this purpose a reference pollutant (phenol) for which the second-order rate coefficient with $\mathrm{SO}_{4}{ }^{--}$is known, was added to the reaction solution at equimolar concentration $(0.515 \mathrm{mM})$ of the model pollutant (DMP; $100 \mathrm{mg} \mathrm{L}^{-1}$, i.e. 0.515 $\mathrm{mM})$.

\section{Analytical Procedures}

DMP concentrations were measured with highperformance liquid chromatography (HPLC, Agilent 1100 Series, USA) equipped with a Diode-Array Detector (DAD) (G1315A, Agilent Series) on an Atlantis C18 $(3.9 \times 150 \mathrm{~mm}, 5 \mu \mathrm{m}$, Waters) column. The mobile phase was 
acetonitrile-water (40:60, v:v) at a flow rate of 1 $\mathrm{mL} \min ^{-1}$. Quantitative analysis was monitored at $220 \mathrm{~nm}$. The column temperature was set at $30^{\circ} \mathrm{C}$ during the measurements. The quantification limit for DMP was $1 \mu \mathrm{g} / \mathrm{mL}$, using a $20 \mu \mathrm{L}$ injection volume. The mobile phase used for phenol quantification consisted of watermethanol-acetic acid (79.2:19.8:1.0; v:v:v) at a

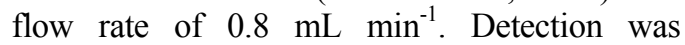
performed at $270 \mathrm{~nm}$. The column temperature and injection volume were set as $30^{\circ} \mathrm{C}$ and 40 $\mu \mathrm{L}$, respectively. The quantification limit for phenol was determined as $1.5 \mathrm{mg} \mathrm{L}^{-1}$ for the method described above. TOC was monitored on a Shimadzu $\mathrm{V}_{\mathrm{CPN}}$ model carbon analyzer. The detection and quantification limits were $50 \mu \mathrm{g} \mathrm{L}$ ${ }^{1}$ and $0.5 \mathrm{mg} \mathrm{L}^{-1}$, respectively. The $\mathrm{pH}$ was monitored using an Orion 720A+ model pHmeter. All measurements were done in duplicate and arithmetic averages were taken throughout the data analyses and calculations.

\section{Results and Discussion}

\section{Effect of Initial Persulfate Concentration}

In order to obtain the optimum PS concentration to treat $100 \mathrm{mg} \mathrm{L}^{-1}$ aqueous DMP solutions by employing the PS/UV-C treatment process, a set of experiments was conducted at varying PS concentrations $(0-60 \mathrm{mM})$ and at $\mathrm{pH} 3$. Figure 1 delineates DMP (a) and TOC (b) removal efficiencies obtained during $60 \mathrm{~min} \mathrm{PMS} / \mathrm{UV}-\mathrm{C}$ oxidation. In addition to the PS/UV-C process, the degradation of DMP with PS oxidation (in the absence of UV-C light) and UV-C photolysis (in the absence of PS) were also examined and the obtained results included in Figure 1 (a) and (b). Experimental results conducted with direct UV-C photolysis resulted in $14 \%$ DMP abatement at $\mathrm{pH} 3$ implying that the selfphotolytic degradation of DMP was not significant under UV-C irradiation. Practically no removal $(\leq 5 \%)$ was obtained by the oxidation of DMP at $30 \mathrm{mM}$ initial PS concentration. TOC removal efficiencies for PS oxidation and UV-C photolysis were also practically negligible within this time period $(\leq 5 \%)$.

As it is evident in Figure 1, PS addition greatly enhanced DMP and TOC abatements as compared to UV-C photolysis which demonstrated that $\mathrm{SO}_{4}{ }^{--}$being generated by UV$\mathrm{C}$ photolysis of PS was mainly responsible for the degradation and mineralization of DMP during PS/UV-C treatment. As can be seen from
Figure 1 (a), DMP removal was always complete at all studied PS concentrations. Complete DMP removals were achieved with the PS/UV-C process after $40 \mathrm{~min}$ (5 $\mathrm{mM}$ PS), $30 \mathrm{~min}$ (10 $\mathrm{mM}$ PS), $15 \mathrm{~min}$ (20, 30 and $40 \mathrm{mM}$ PS) and $20 \mathrm{~min}$ (60 mM PS). The DMP degradation and mineralization increased gradually as the initial concentration of PS increased from $5 \mathrm{mM}$ to 30 $\mathrm{mM}$. For example, the removal of DMP at $5 \mathrm{~min}$ increased from $35 \%$ with $5 \mathrm{mM}$ to $83 \%$ with 30 $\mathrm{mM}$ PS at initial $\mathrm{pH} 3$. However, further increase in PS concentration to 40 and $60 \mathrm{mM}$, decreased the degradation rate of DMP. This is thought to be a consequence of the well-known free radical scavenging effect of excessive PS concentrations (Criquet and Leitner, 2009);

$\mathrm{S}_{2} \mathrm{O}_{8}^{2-}+\mathrm{SO}_{4}^{-\bullet} \rightarrow \mathrm{SO}_{4}^{2-}+\mathrm{S}_{2} \mathrm{O}_{8}^{\bullet-}$
$\mathrm{k}=6.1 \times 10^{9} \mathrm{M}^{-1} \mathrm{~s}^{-1}$

The optimum PS concentration for DMP degradation was $30 \mathrm{mM}$. Increasing the initial PS concentration also had a positive effect on TOC removal efficiencies; overall TOC removals increased from $38 \%$ to $100 \%$ when 5 $\mathrm{mM}$ and $60 \mathrm{mM}$ PS was used, respectively.

The degradation of DMP with the PS/UV-C process followed pseudo-first-order kinetics $(\mathrm{d}[\mathrm{DMP}] / \mathrm{dt}=\mathrm{k} \times[\mathrm{DMP}])$ with respect to DMP concentration. Results of the PS/UV-C treatment experiments indicated that the highest DMP removal rate coefficient $\left(\mathrm{k}_{\mathrm{DMP}}=0.4493 \mathrm{~min}^{-1}\right)$ was achieved at a PS concentration of $30 \mathrm{mM}$ within the studied PS concentration range (Table 1). Further increase of the PS concentration reduced the DMP removal rates to $0.2957 \mathrm{~min}^{-1}$ and $0.2261 \mathrm{~min}^{-1}$ for $40 \mathrm{mM}$ and $60 \mathrm{mM}$ PS concentrations, respectively.

Table 1. Effect of initial PS concentration on DMP removal rates $\left(\mathrm{DMP}=100 \mathrm{mg} \mathrm{L}^{-1}\right.$; $\mathrm{TOC}=$ $60 \mathrm{mg} \mathrm{L}^{-1} ; \mathrm{pH}=3$ ).

\begin{tabular}{lc}
\hline Initial PS (mM) & $\mathrm{k}_{\mathrm{DMP}}\left(\mathrm{min}^{-1}\right)$ \\
\hline 5 & 0.0715 \\
10 & 0.2165 \\
20 & 0.2740 \\
30 & 0.4493 \\
40 & 0.2957 \\
60 & 0.2261 \\
\hline
\end{tabular}

Besides kinetics, a more comprehensive way to compare the effectiveness of UV-based technologies has been adopted by the 
Photochemistry Commission of the International Union of Pure Chemistry; namely the electrical
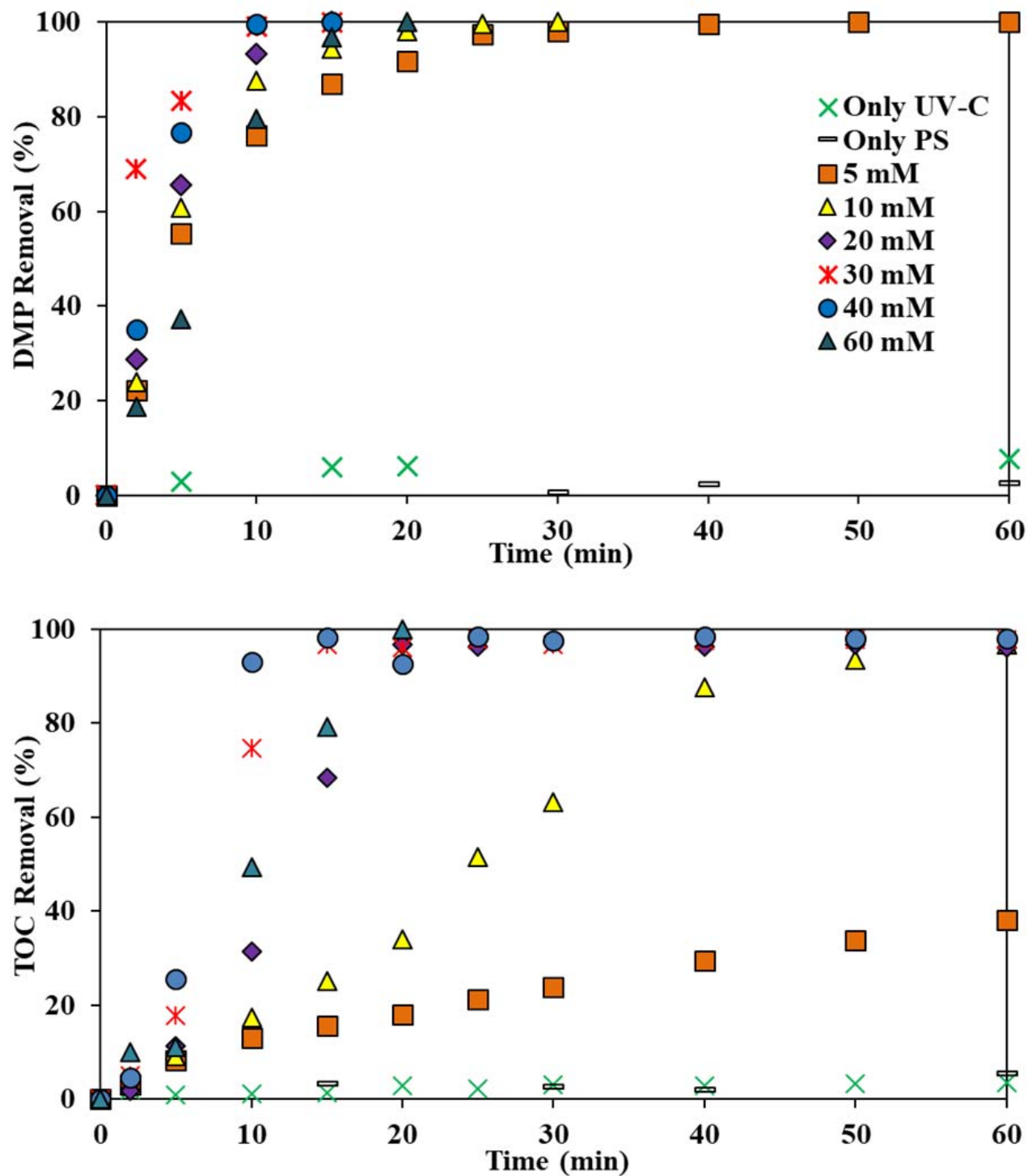

Fig 1. Effect of initial PS concentration on DMP (a) and TOC (b) removal efficiencies obtained during $\mathrm{PS} / \mathrm{UV}-\mathrm{C}$ treatment $\left(\mathrm{DMP}=100 \mathrm{mg} \mathrm{L}^{-1} ; \mathrm{TOC}=60 \mathrm{mg} \mathrm{L}^{-1} ; \mathrm{pH}=3\right)$.

$\mathrm{EE} / \mathrm{O}$ measures the electrical energy $(\mathrm{kWh})$ required to reduce the concentration of a contaminant by an order of magnitude in a $1 \mathrm{~m}^{3}$ water or wastewater and is described by the following equation:

$\mathrm{EE} / \mathrm{O}=38.4 \times \mathrm{P} /(\mathrm{V} \times \mathrm{k})$

where $\mathrm{P}$ is the lamp power $(\mathrm{kW}), \mathrm{V}$ is the reactor volume (L), and $\mathrm{k}$ is the pseudo-first-order rate constant of the compound degradation $\left(\mathrm{min}^{-1}\right)$.
The EE/O values for DMP (100 $\left.\mathrm{mg} \mathrm{L}^{-1}\right)$ degradation with $\mathrm{PS} / \mathrm{UV}-\mathrm{C}$ treatment at various initial PS concentrations were calculated and shown in Figure 2 with the smallest EE/O value representing the more energy efficient treatment condition. For the optimum initial PS concentration of $30 \mathrm{mM}$, the minimum EE/O value for DMP degradation was calculated as $1.79 \mathrm{kWh} \mathrm{m}^{-3}$ order $^{-1}$. From Figure 2 it can be 
concluded that applying an optimum PS concentration can minimize the EE/O value.

Determination of the second-order reaction rate constant of DMP with $\mathrm{SO}_{4}{ }^{--}$

The competition kinetic studies were carried out to determine the second-order reaction rate constant of DMP with $\mathrm{SO}_{4}{ }^{-}$using phenol whose second-order reaction rate coefficient with $\mathrm{SO}_{4}{ }^{-}$ is known $\left(\mathrm{k}_{\text {SO4- }- \text { phenol }}=8.8 \times 10^{9} \mathrm{M}^{-1} \mathrm{~s}^{-1}\right)$ as the reference compound (Lindsey and Tarr, 2000; Liang and $\mathrm{Su}, 2009)$. The following expression was applied for the estimation of the secondorder reaction rate coefficient;

$\ln [\mathrm{DMP}]_{\mathrm{o}} /[\mathrm{DMP}]_{\mathrm{t}}=$

$\mathrm{k}_{\mathrm{SO} 4 \bullet-\mathrm{DMP}} / \mathrm{k}_{\mathrm{SO} 4 \bullet-\text {,phenol }} \times \ln [\mathrm{phenol}]_{\mathrm{o}} /[\mathrm{phenol}]_{\mathrm{t}}$ (Eq. 4)

where $\mathrm{k}_{\mathrm{SO} 4 \bullet-, \mathrm{DMP}}$ and $\mathrm{k}_{\mathrm{SO} 4 \bullet-\text {,phenol }}$ are second-order reaction rate constants (in $\mathrm{M}^{-1} \mathrm{~s}^{-1}$ ) for the reactions between the DMP (target compound) and phenol (reference compound) with $\mathrm{SO}_{4}{ }^{\circ-}$, respectively.

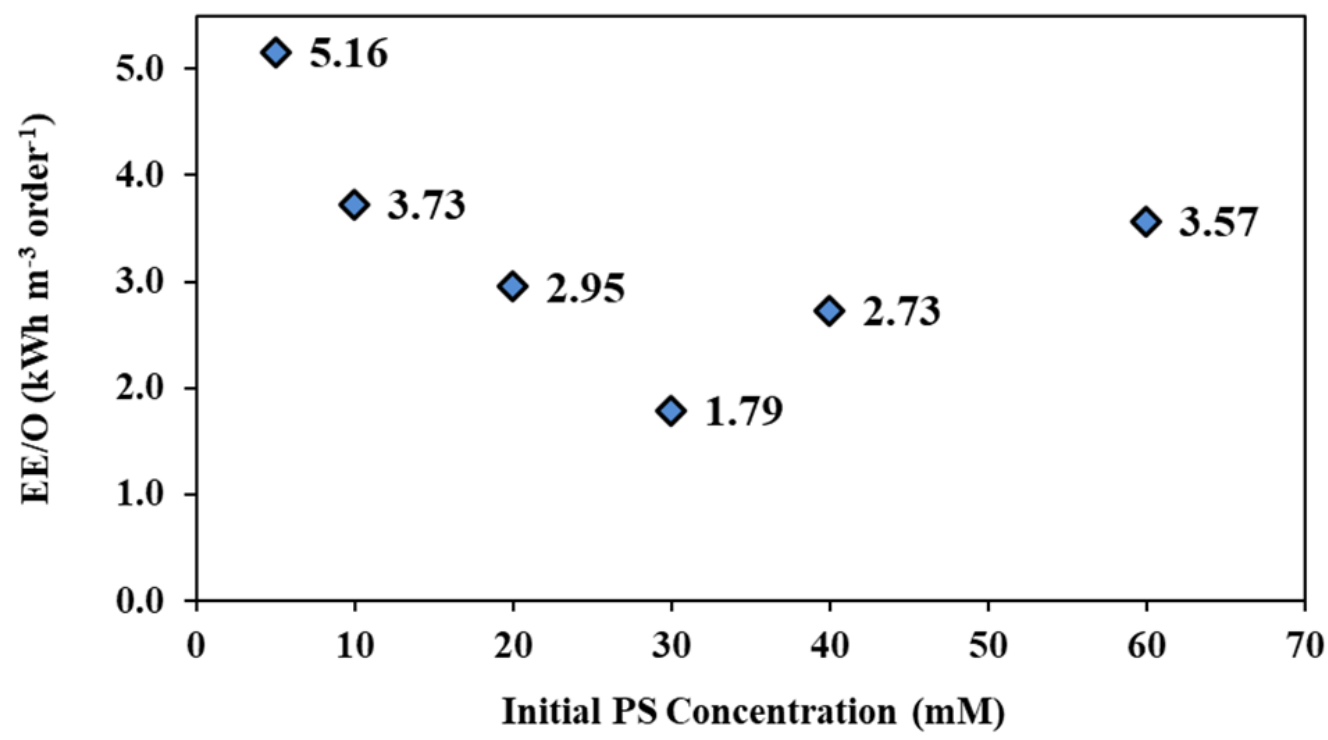

Fig 2. The calculated $E E / O$ values for DMP degradation by the $P S / U V-C$ treatment $\left(D M P=100 \mathrm{mg} \mathrm{L}^{-1}\right.$; $\mathrm{TOC}=60 \mathrm{mg} \mathrm{L}^{-1} ; \mathrm{pH}=3$ )

The second-order rate constant between DMP and $\mathrm{SO}_{4}{ }^{--}$was calculated as $1.47 \times 10^{9} \mathrm{M}^{-1} \mathrm{~s}^{-1}$ by using the first-order rate constants determined for DMP $\left(0.0192 \mathrm{~min}^{-1}\right)$ and phenol $\left(0.1147 \mathrm{~min}^{-1}\right)$ as well as $\mathrm{k}_{\mathrm{SO} 4 \bullet-\text {,phenol }}(=$ $\left.8.8 \times 10^{9} \mathrm{M}^{-1} \mathrm{~s}^{-1}\right)$.

Comparison of PS/UV-C with PMS/UV-C and $\mathrm{HP} / \mathrm{UV}-\mathrm{C}$ treatment processes

To compare the performance of PS/UV-C with PMS/UV-C and HP/UV-C processes, the experiments were carried out at initial DMP concentration of $100 \mathrm{mg} \mathrm{L}^{-1}$ and $\mathrm{pH} \mathrm{3}$, with an initial oxidant concentration of $5 \mathrm{mM}$. The degradation efficiency of DMP with the PS/UV-C process was $76 \%$ after $10 \mathrm{~min}$, which was much higher than $59 \%$ and $56 \%$ obtained for PMS/UV-C and HP/UV-C treatments, respectively (Figure 3).
DMP was completely degraded after $40 \mathrm{~min}$ treatment with the PS/UV-C process, whereas $100 \%$ DMP removal was realized for PMS/UV-C and HP/UV-C treatments after 60 min. As it is evident form Figure 3, after 60 min treatment, the highest TOC removal efficiency was obtained as $38 \%$ for PS/UV-C oxidation, whereas only $27 \%$ TOC removal was achieved during PMS/UV-C and HP/UV$\mathrm{C}$ treatments. The $\mathrm{k}_{\mathrm{DMP}}$ values of the investigated treatment processes exhibited the following decreasing order; PS/UV-C (0.1566 $\left.\min ^{-1}\right)>\mathrm{HP} / \mathrm{UV}-\mathrm{C}\left(0.0765 \mathrm{~min}^{-1}\right) \approx \mathrm{PMS} / \mathrm{UV}-$ C $\left(0.0715 \mathrm{~min}^{-1}\right)$ at an initial oxidant concentration of $5 \mathrm{mM}$, indicating that the $\mathrm{PS} / \mathrm{UV}-\mathrm{C}$ treatment process was superior over $\mathrm{HP} / \mathrm{UV}-\mathrm{C}$ and PMS/UV-C treatments on the basis of DMP removal kinetics and TOC removal efficiencies. 


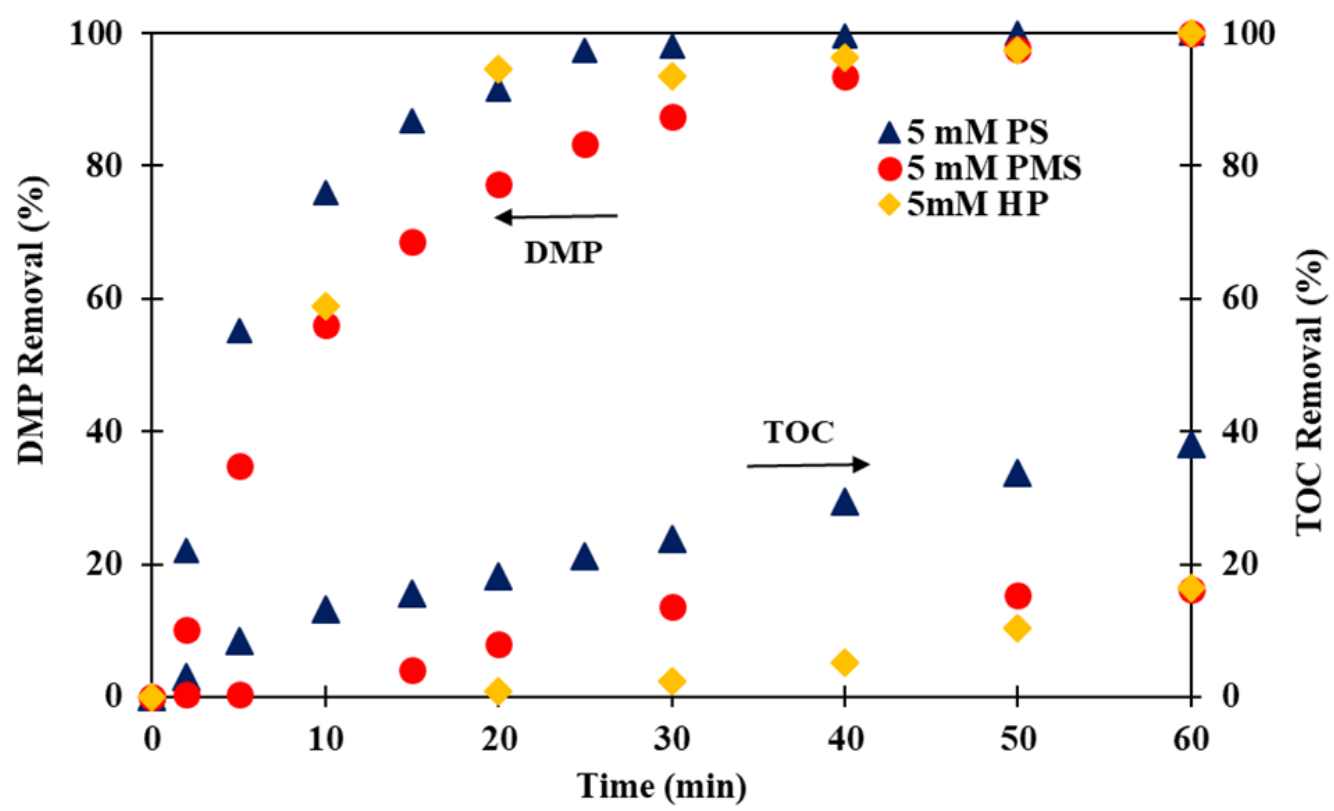

Fig 3. Comparison of DMP and TOC removal efficiencies obtained during PS/UV-C, PMS/UV-C and $\mathrm{HP} / \mathrm{UV}-\mathrm{C}$ treatments $\left(\mathrm{DMP}=100 \mathrm{mg} \mathrm{L}^{-1} ; \mathrm{TOC}=60 \mathrm{mg} \mathrm{L}^{-1} ; \mathrm{PS}=\mathrm{PMS}=\mathrm{HP}=5 \mathrm{mM} ; \mathrm{pH}=3\right.$ ).

\section{Conclusions}

In the present study, the treatment performance of the persulfate (PS)/UV-C process for the degradation of dimethyl phthalate (DMP), being selected as a model phthalate ester and micropollutant, was evaluated at an initial DMP concentration of $100 \mathrm{mg} \mathrm{L}^{-1}(0.515 \mathrm{mM})$ and an initial $\mathrm{pH}$ of 3 . The effect of initial PS concentration on DMP and total organic carbon (TOC) removals rates was examined. The following conclusions could be drawn from the present work;

- The PS/UV-C process was found to be effective in the degradation and mineralization of DMP. DMP degradation was rapid and complete within 10-40 min treatment time depending on the initial PS oxidant concentration $(0-60 \mathrm{mM})$. Increasing the initial PS concentration resulted in a significant enhancement of TOC removal; over $90 \%$ TOC removals could be achieved at elevated PS concentrations ( $\geq 10 \mathrm{mM}$ ).

- Pseudo-first-order DMP degradation rate constants increased with increasing the initial PS concentration and decreased above optimum value. The highest pseudo-firstorder DMP degradation rate constant was found as $0.4495 \mathrm{~min}^{-1}$ for $30 \mathrm{mM}$ PS.
- The EE/O for complete DMP degradation was calculated as $1.79 \mathrm{kWh} \mathrm{m}^{-3}$ order $^{-1}$ for the optimum initial PS concentration of 30 $\mathrm{mM}$.

- The results of the competitive kinetics experiments, where phenol was used as the probe reference compound, showed that DMP reacted rapidly with $\mathrm{SO}_{4}{ }^{\circ}$, with the second-order rate constant of $1.47 \times 10^{9} \mathrm{M}^{-1} \mathrm{~s}^{-}$ 1 .

- The PS/UV-C process was found to be more effective for not only DMP removal but also DMP mineralization than the PMS/UV-C and HP/UV-C processes at an initial oxidant concentration of $5 \mathrm{mM}$ and at $\mathrm{pH} 3$.

\section{Acknowledgements}

The financial support of Istanbul Technical University under Project Number 34332 and Science Academy, Turkey, under the grant of the "Young Scientist Awards Program (BAGEP)" are appreciated.

\section{References}

Abdel daiem, M.M., Rivera-Utrilla, J., Ocampo-Pérez, R., Méndez-Díaz, J.D., Sánchez-Polo, M. 2012. Environmental impact of phthalate acid esters and their removal from water and sediments by different technologies e a review. Journal 
of Environmental Management, 109, 164178.

Anipsitakis, G.P., Dionysiou, D.D., 2004. Transition metal/UV-based advanced oxidation technologies for water decontamination. Applied Catalysis B: Environmental, 54, 155-163.

Bauer, M.J., Herrmann, R., Martin, A., Zellmann, H. 1998. Chemodynamics, transport behaviour and treatment of phthalic acid esters in municipal landfill leachates. Water Science and Technology, 38, 185-192.

Baxendale, J.H., Wilson, J.A. 1957. The photolysis of hydrogen peroxide at high light intensities. Transactions Faraday Society, 53, 344-356.

Bolton, J.R., Bircher, K.G., Tumas, W., Tolman, C.A. 2001. Figures of merit for the technical development and application of advanced oxidation technologies for both electric and solar driven systems. Pure Applied Chemistry 73, 627-637.

Clara, M., Windhofer, G., Hartl, W., Braun, K., Simon, M., Gans, O., Scheffknecht C., Chovanec, A. 2010. Occurrence of phthalates in surface runoff, untreated and treated wastewater and fate during wastewater treatment. Chemosphere, 79, 1017-1018.

Criquet, J., Leitner, K.V.N. 2009. Degradation of acetic acid with sulfate radical generated by persulfate ions photolysis. Chemosphere, 77, 194-200.

Dargnat, C., Teil, M.J., Chevreuil, M., Blanchard, M. 2009. Phthalate removal throughout wastewater treatment plant: case study of Marne Aval station (France). Science of the Total Environment, 407, 1235-1244.

Fierens, T., Servaes, K., Van Holderbeke, M., Geerts, L., De Henauw, S., Sioen, I., Vanermen, G. 2012. Analysis of phthalates in food products and packaging materials sold on the Belgian market. Food Chemistry and Toxicology, 50, 2575-2583.

He, X., de la Cruz, A.A., Dionysiou, D.D. 2013. Destruction of cyanobacterial toxin cylindrospermopsin by hydroxyl radicals and sulfate radicals using UV-254nm activation of hydrogen peroxide, persulfate and peroxymonosulfate. Journal of
Photochemistry and Photobiology A: Chemistry, 251, 160-166.

Kang, Y., Man, Y.B., Cheung, K.C., Wong, M.H. 2012. Risk assessment of human exposure to bioaccessible phthalate esters via indoor dust around the Pearl River Delta. Environmental Science and Technology, 46, 8422-8430.

Kolpin, D.W., Furlong, E.T., Meyer, M.T., Thurman, E.M., Zaugg, S.D., Barber, L.B., Buxton, H.T. 2002. Pharmaceuticals, hormones, and other organic wastewater contaminants in US streams, 1999-2000: A national reconnaissance. Environmental Science and Technology, 36, 1202-1211.

Liang, C., Su, H.W. 2009. Identification of sulfate and hydroxyl radicals in thermally activated persulfate. Industrial and Engineering Chemistry Research, 48, 5558-5562.

Lindsey, M.E., Tarr, M.A. 2000. Inhibition of hydroxyl radical reaction with aromatics by dissolved natural organic matter. Environmental Science and Technology, 34, 444-449.

Mark, G., Schuchmann, M.N., Schuchmann, H., von Sonntag, C. 1990. The photolysis of potassium peroxodisulphate in aqueous solution in the presence of tert- butanol: a simple actinometer for $254 \mathrm{~nm}$ radiation. Journal of Photochemistry and Photobiology A: Chemistry, 55, 157-168.

Neta, P., Huie, R.E., Ross, A.B. 1988. Rate constants for reactions of inorganic radicals in aqueous solution. Journal of Physical and Chemical Reference Data, 17, 1027-1385.

Oliver, R., May, E., Williams, J. 2005. The occurrence and removal of phthalates in a trickle filter STW. Water Research, 39, 4436-4444.

Ölmez-Hanc1, T., Imren, C., Arslan-Alaton, I., Kabdaşl1, I., Tünay, O. 2009. $\mathrm{H}_{2} \mathrm{O}_{2} / \mathrm{UV}-\mathrm{C}$ oxidation of potential endocrine disrupting compounds: a case study with dimethyl phthalate. Photochemical and Photobiological Science, 8, 620-627.

Ölmez-Hanc1, T., Imren, C., Kabdaşl1, I., Tünay, O., Arslan-Alaton, I. 2011. Application of the UV-C photo-assisted peroxymonosulfate oxidation for the mineralization of dimethyl phthalate in 
aqueous solutions. Photochemical and Photobiological Sciences, 10, 408-413.

Venkata Mohan, S., Shailaja, S., Rama Krishna, M., Sarma, P.N. 2007. Adsorptive removal of phthalate ester (diethyl phthalate) from aqueous phase by activated carbon: a kinetic study. Journal of Hazardous Materials, 146, 278-282

Xua, B., Gao, N.Y., Sun, X.F., Xia, S.J., Rui, M., Simonnot, M.O., Causserand, C., Zhao, J.F. 2007. Photochemical degradation of diethyl phthalate with $\mathrm{UV} / \mathrm{H}_{2} \mathrm{O}_{2}$. Journal of Hazardous Materials, B139, 132-139.

Yang, Y., Pignatello, J.J., Ma, J., Mitch, W.A. 2016. Effect of matrix components on
$\mathrm{UV} / \mathrm{H}_{2} \mathrm{O}_{2}$ and $\mathrm{UV} / \mathrm{S}_{2} \mathrm{O}_{8}{ }^{2-}$ advanced oxidation processes for trace organic degradation in reverse osmosis brines from municipal wastewater reuse facilities. Water Research, 89, 192-200.

Yuan, B.L., Li, X.Z., Graham, N. 2008. Aqueous oxidation of dimethyl phthalate in a $\mathrm{Fe}(\mathrm{VI})-\mathrm{TiO}_{2}-\mathrm{UV}$ reaction system. Water Research, 42, 1413-1420.

Zhou, Y.R., Zhu, W.P., Liu, F.D., Wang, J.B., Yang, S.X. 2007. Catalytic activity of $\mathrm{Ru} / \mathrm{Al}_{2} \mathrm{O}_{3}$ for ozonation of dimethyl phthalate in aqueous solution. Chemosphere, 66, 145-150. 